\title{
Justyna Sujka
}

Uniwersytet Łódzki

\section{SZYLDY W MIEŚCIE LODZI CORAZ BARDZIEJ OBCE}

\author{
RZECZ O ADAPTACJI ZAPOŻYCZEŃ W CHREMATONIMACH
}

SŁOWA KLUCZOWE: chrematonimy marketingowe, firmonimy, zapożyczenia, Łódź

Werbalne komunikaty w przestrzeni miejskiej, na których widnieje szereg nazw własnych, są niejednolite, zarówno pod względem treści, jak i walorów stricte fizycznych. Obraz miasta jawi się jako silnie skomercjalizowany. Poruszając się po Łodzi, mijamy olbrzymią liczbę znaków drogowych, tablic informacyjnych czy banerów reklamowych. $Z$ językoznawczego punktu widzenia możemy dostrzec na nich m.in. toponimy miejskie (np. nazwy ulic czy skwerów), zoonimy (na ogłoszeniu w sprawie zaginięcia psa), a niekiedy na murach przezwiska, nazywane w terminologii onomastycznej - antroponimami. Przedmiotem niniejszej pracy jest adaptacja chrematonimów marketingowych określających nazwę firm działających na terenie aglomeracji łódzkiej. Najbardziej akceptowalnym w polskiej literaturze naukowej określeniem charakteryzującym tę grupę chrematonimów użytkowych są firmonimy. Jak wyjaśnia A. Gałkowski: firmonimy, jako nazwy własne firm oraz ich produktów/ustug (...), maja postać rozwiniętej marki lub sq - choćby potencjalnie - w toku procesu transformacyjnego, który kończy się osiagnięciem statusu marki [2012, s. 64].

Łódź, będąca trzecim co do wielkości miastem w Polsce, do końca II wojny światowej uchodziła za miasto wielu kultur, narodowości i wyznań. Historia Łodzi związana jest przede wszystkim z rozwojem przemysłu włókienniczego, do którego przyczyniły się w największym stopniu cztery narodowości: Polacy, Niemcy, Rosjanie i Żydzi. Wielojęzyczność była wówczas zjawiskiem powszechnym. U szczytu rozwoju miasta, towary opisywano w języku polskim, niemieckim, rosyjskim oraz w jidysz, zaś szyldy fabryk, sklepów i zakładów tworzyły wielokulturową mozaikę, stanowiącą o językowym obrazie przemysłowego miasta. Obecnie Łódź jest miastem, w którym (podobnie, jak ma to miejsce w skali ogólnopolskiej) następuje rozwój sektora usług, a w nim firmy posiadające nazwy rodzime zostają zastępowane przez międzynarodowe koncerny, a także przez firmy polskie rezygnujące z nazw ojczystych ze względu na ułatwienia w szeroko pojętej komunika- 
cji na arenie międzynarodowej. Ledwo co opanowano, w mniejszym lub większym stopniu, wymowę nazw sieci sklepów wielkopowierzchniowych, takich jak np. Tesco, Carrefour czy Leroy Merlin (nazywany także lirojem merlinem), a już w najnowszych doniesieniach prasowych [Brzózka, 2012] możemy przeczytać, że swoją działalność w Łodzi zaczyna prowadzić Hewlett-Packard (w skrócie HP) czy PricewaterhouseCoopers (w skrócie PwC). Jak łodzianie radzą sobie z nazywaniem firm, których nazwy nie potrafią wymówić, a niekiedy nawet nie rozumieją?

Nazwy handlowe pojawiające się na szyldach mają za zadanie nie tylko identyfikować sklepy, kina czy restauracje, ale również odróżniać je od pozostałych tego typu obiektów [Jaros, 2008, s. 357]. Nie można zapominać, że w swej istocie stanowią także tekst reklamowy, którego zadaniem jest nakłonienie klienta do odwiedzenia danego miejsca. Jak pisze Jerzy Bralczyk, komunikat reklamowy powinien być atrakcyjny, sugestywny, zrozumiały, zwięzły, oryginalny i łatwy do zapamiętania [2000]. Obcobrzmiące firmonimy tylko pozornie nie spełniają tych postulatów, ponieważ nazwy w językach obcych wydają się Polakowi atrakcyjnie i równie skutecznie kuszą klientów. W idealnym przypadku nie powinny również sprawiać problemów w wymowie i odmianie, gdyż inaczej wywołają w potencjalnym kliencie poczucie obcości. Co ciekawe jednak, ze względu na dziesięciolecia cenzury oraz kreowania nazewnictwa nacechowanego ideologicznie, Polacy rzeczy nieznane i obce, uważają za lepsze. Nazwy obce sa wartościowane pozytywnie zarówno dzięki ich walorom brzmieniowym, jak i konotacji, na co zwraca uwagę V. Jaros [2008, s. 357].

Obcobrzmiące firmonimy — trudne w odmianie i wymowie, utożsamiane są z kulturą Zachodu, czyli w stereotypowym rozumieniu kojarzone z nowoczesnością. Przykładem mogą być dwie marki modowe łódzkiej firmy Redan: Top Secret oraz Troll. Pisownia sugeruje zachodnie pochodzenie towarów, a poniekąd nawiązywanie do najnowszych trendów w modzie. Marki, choć nie brzmią rodzimie, budzą konotacje pozytywne. Marka odzieży Top Secret kładzie nacisk na cechy pożądane przez obie płcie — kobietom kojarzy się z tajemniczością, a mężczyznom z tajną misją do wykonania, byciem tajnym agentem. Słowo top sugeruje towar z najwyższej półki i najlepszej jakości. Na tym przykładzie można zauważyć, że słowa budujące nazwy własne wcale nie tracą swojego pierwotnego sensu.

Większość ankietowanych przeze mnie łodzian otwarcie przyznaje, że ma problemy z deklinacją oraz wymową nazw, które widnieją na szyldach. Problemy z odmianą nazw obcojęzycznych [Cieślikowa, 2008, s. 129-130] powodują, że są one uzupełniane przez słowa oznaczające miejsce, w którym świadczona jest dana usługa. I tak, kiedy prosiłam w ankietach od odmienienie nazwy Silver Screen, poprzedzana była ona słowem kino, zaś Piazza Cafe espresso słowem kawiarnia. Aby uniknąć substytucji firmonimów przez określenia miejsca czy swobodne skojarzenia klientów, przedsiębiorstwa chętnie posługują się dodatkowymi określeniami sugerującymi rodzaj wykonywanej działalności, lecz zamiast polskiego słowa zakład, jako element nazwy własnej pojawiają się zapożyczenia z języka angielskiego słowa takie jak: salon, centrum czy mniej upowszechnione wellness. W Ło- 
dzi spotkać możemy nie tylko salon urody czy fryzjersko-kosmetyczny, ale również szyldy zawierające takie połączenia jak: salon sukni ślubnych, salon mebli, glazury i terakoty, łazienek, optyczny, ezoteryczny, kwiatowy, jubilerski, kulturystyczny, a nawet pielęgnacji psów, zoologiczny i pralniczy. Salon ma wywoływać świadomość dużej powierzchni danego zakładu i poczucie ekskluzywności [Matusiak, 2010, s. 295], lecz trudno o nie, gdy napotykamy tabliczkę z napisem Salon paznokcia czy Salon drobiu. Wiele firm załącza w swojej nazwie również słowo centrum czy instytut, sugerujące profesjonalizm, miejsce, gdzie pracują wybitni specjaliści w swojej dziedzinie.

Łodzianie, wybierając chrematonimy, chętnie korzystają z międzynarodowych morfemów. W latach dziewięćdziesiątych powstawały firmy, które swoją nazwą podkreślały współpracę, najczęściej w formie handlu, z kontrahentami zagranicznymi. Nastąpił wówczas prawdziwy wysyp przedsiębiorstw zawierających w swoich członach słowa import-export lub ich morfemy. Do dziś istnieją jednak takie firmy, których główną działalności nie jest handel międzynarodowy, a mimo to używają morfemu -ex rodzącego konotacje z szeroko pojętym transportem ${ }^{1}$. Przykładem może być łódzka firma Sław-ex - producent mebli, którego firmonim zrodził się z połączenia imienia właściciela firmy (Sławomira) oraz morfemu -ex. Jednak zastosowanie morfemu -ex na początku firmonimu kojarzy się obecnie z czymś byłym, także z popularną obecnie $\mathrm{w}$ języku polskim kalką z języka angielskiego jak eks-mąż czy eks-żona nazywani skrótowo przez swoich byłych małżonków również eks. Stąd w pewną konsternację wprowadził mnie szyld łódzkiego sklepu z artykułami ogrodniczymi Ex Flor.

Współcześnie, gdy współpraca międzynarodowa, szczególnie po wejściu Polski do Unii Europejskiej, wydaje się być czymś naturalnym, firmy, które w nazwie zawierają słowa import-export odbierane są, szczególnie przez młodsze pokolenie konsumentów, z pewnym dystansem, ponieważ sugerują powstanie firmy na początku lat dziewięćdziesiątych, a zarazem pewne zaszłości historyczne i brak nowoczesności, co odstrasza współczesnego klienta. Dzisiejsza kultura konsumpcyjna, którą częścią stały się nazwy własne, zamiast tradycji promuje bowiem nowoczesność.

Po roku 1989, gdy prerogatywy do nadawania nazw własnych oddano osobom prywatnym, w firmonimach stosowano również morfemy sugerujące polskie pochodzenie. Niestety, często firmonim nie informuje tutaj konsumenta o przedmiocie działalności danego przedsiębiorstwa. Przykładowo pod łódzką nazwą Zbych-pol odkrywamy hurtownię obrusów i pościeli. Jak należy jednak odszyfrować znaczenie firmonimu przedsiębiorstwa oferującego profesjonale środki czystości Just-Pol? Czy to kolejne złożenie części imienia i morfemu -pol, a może angielska zabawa słowna, pod którą kryją się słowa just polish, czyli 'po prostu wypoleruj', a samą nazwę należałoby wymawia jako [dzıst 'pa:1IJ]? Ciekawe połączenie reprezentuje

${ }^{1}$ Ponadto pokoleniu dokonującemu transakcji w czasach funkcjonowania sklepów Pewex morfem -ex będzie kojarzył się z towarami luksusowymi. 
również firmonim Franspolexu — importera końcówek serii takich produktów jak: meble, tekstylia, odzież, obuwie, który zawiera zarówno morfemy -pol oraz -ex.

$\mathrm{Na}$ ulicach Łodzi spotkać można teraz szyldy z międzynarodowymi morfemami jak np. inter- w znaczeniu 'między' lub jako derywat od słowa international, czyli 'międzynarodowy'; multi- w znaczeniu 'wiele, kilka' [Waszakowa, 2005]. Jednak i tutaj łatwo o pomylenie przedmiotu działalności firmy. Firmonim Inter Vega budzi konotacje z tak dobrze już funkcjonującym w polskim języku słowami jak np. weganin, wegański, lecz za firmonimem Inter Vega kryje się przedsiębiorstwo ubezpieczeniowe.

Interesujące jest również występowanie wielu łódzkich firm, które swą nazwę rozpoczynają od morfemu euro- sugerując, że obszar ich działalności dotyczy areny europejskiej. Na terenie aglomeracji łódzkiej występuje wiele firm działających na poziomie lokalnym i regionalnym, stanowiących filie ogólnopolskich sieci m.in.: sklep zoologiczny Euro-Zoo, Euro Apteka czy Euro-Kom będący, nie, jak być może zdążyli już się Państwo zasugerować, producentem komputerów, lecz kominków i wyrobów kominkowych. Ponadto w Łodzi funkcjonuje również firma zawierająca złożenie Euro-Kom świadcząca usługi kominiarskie. W Łodzi powstała także hurtownia artykułów kosmetycznych i fryzjerskich o firmonimie Euro-fryz. Jednak przedsiębiorstwo choć importuje produkty z krajów europejskich, to posiada zaledwie dwie placówki w mieście.

Niekiedy zapis firmonimów, szczególnie tych, w których występująniezaadaptowane w pełni zapożyczenia, utrudnia nam ich przeczytanie. Przykładowo przedstawiciele związani z branżą włókienniczą w regionie łódzkim nie mogą ustalić wspólnej pisowni zapożyczenia z języka angielskiego słowa overlock, które zapisywane jest jako overlok czy owerlok, lub też zachowana jest oryginalna pisownia tego ściegu krawieckiego.

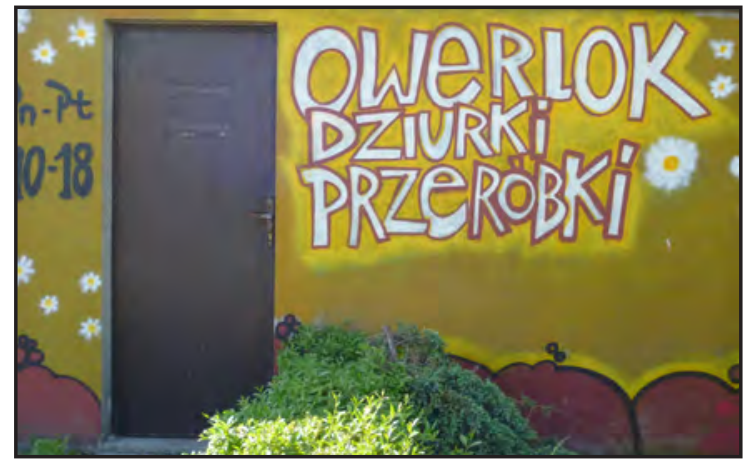

Fot. 1. Owerlok przy ul. Paderewskiego w Łodzi

Właściciele małych sklepów, których klientami są głównie okoliczni mieszkańcy, wolą pozostać przy polskobrzmiących nazwach, często na szyldach umieszczając jeszcze rzeczowy opis świadczonych usług. Jednakże w chrematonimach marketingowych małych firm także możemy odnaleźć imiona czy nazwiska o obcobrzmiącej pisowni np. Andrea, Cristine czy Caterina. Przy badaniu funkcji semantycznej chromatonimów marketingowych, należy pamiętać, że intencja autora nazwy i zarazem jej pierwszego użytkownika odgrywa kluczową rolę [Siwiec, 2003a, s. 262].

Większość szyldów obcojęzycznych w Łodzi można zauważyć w Śródmieściu. Wyjątkiem są duże centra handlowe, które ulokowane są w różnych częściach miasta. W tym miejscu warto zwrócić uwagę na to, jak daleki wpływ na toponimię mają sklepy wielkopowierzchniowe, którym dedykowane są obecnie nazwy przystanków komunikacji miejskiej tj. Manufaktura i Chocianowice-Ikea. 
Poza pierwotnym zakresem znaczeniowym zaczyna funkcjonować również firmonim niemieckiej sieci sklepów Rossman, który dla wielu mieszkańców Łodzi oznacza już nie tylko właściwy sklep marki Rossman, lecz każdy podobny zaopatrujący w produkty kosmetyczne i chemii gospodarczej. Dzisiaj pytając: „Czy jest tu w okolicy jakiś Rossmann?”, mamy zazwyczaj na myśli sklep określany w rodzimym języku mianem sklepu z artykułami chemicznymi czy chemią kosmetyczną.

W kategorii chrematonimów marketingowych wciąż można dostrzec wyraźna preferencję nazw anglo-amerykańskich [Siwiec, 2003b, s. 549], a Łódź nie jest w tej kwestii wyjątkiem. W Śródmieściu można spotkać także dodatkowe szyldy w obcych językach. E. Mańczak-Wohlfeld wymienia następujące przyczyny dominacje języka angielskiego na świecie: wpływ Imperium Brytyjskiego i kolonizacji, rewolucja przemysłowa, imperializm ekonomiczny USA, uznanie języka angielskiego za język dyplomacji w XX wieku, rozwój nauk ścisłych dokumentowanych w języku angielskim, a także rozwój mediów i reklamy, który na dużą skalę objął wpierw Stany Zjednoczone Ameryki Północnej [2006, s.10-12].

Zaprezentowane przykłady wcale nie świadczą o negatywnym wymiarze obcości. Coraz więcej nazw, sklepów czy rodzimych restauracji czerpie firmonimy z języków obcych, chcąc podkreślić przy tym obszar swojej działalności i zaintrygować konsumentów oryginalnością nazwy. W kulturze skomercjalizowanej nazwa nie pełni już tylko funkcji identyfikującej, ale również powinna promować firmę. Konieczność wyboru między swoim i znanym, a obcym i nieznanym jest cechą typową dla życia w dużych miast, gdzie szybko następuje proces globalizacji, również na polu językowym.

Omówione przykłady łódzkich firmonimów pokazują, że niejednolitość oznaczeń powoduje problemy w ich użyciu — trudności w odmianie oraz w wymowie, lecz dobrze dobrany chrematonim marketingowy, nawet obcego pochodzenia, może zachęcić łodzian do korzystania z usług danej firmy. Jeżeli użytkownik języka poczuje się

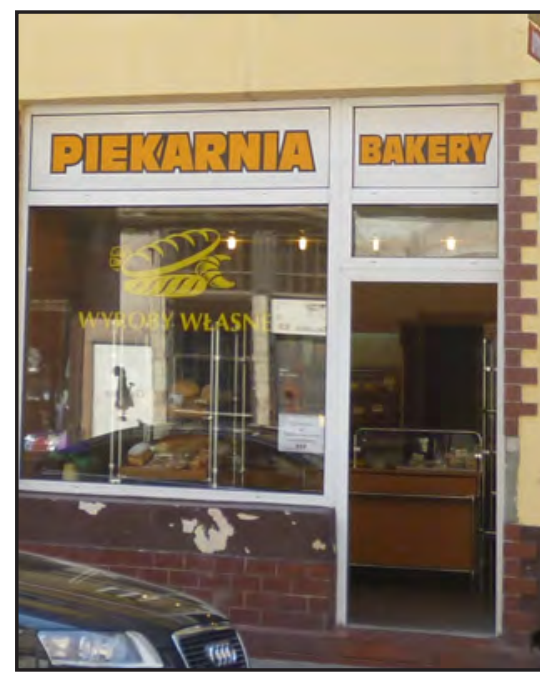

Zdj. 2. Piekarnia-Bakery przy ul. Więckowskiego w Łodzi niepewny — znajdzie odpowiednie określenie, żeby w sposób opisowy wyrazić daną nazwę, dodając do niej rodzaju zakładu. Chrematonim zastępowany jest określeniami położenia, tj. ulicy, dzielnicy czy nazwą większego kompleksu handlowego.

Podziat na ,swoich" $i$ obcych należy od wieków do najważniejszych elementów tożsamości [Rzetelska-Feleszko, 2006, s. 70]. Szyldy w mieście Łodzi tworzą marketingowy krajobraz, w którym różnice między swojskością a obcością bardzo powoli się zacierają. $\mathrm{O}$ adaptacji firmonimów zawierających obcobrzmiące słowa decyduje użytkownik języka, lecz ten ma coraz mniejsze możliwości wyboru, gdyż właściciele łódzkich firm rzadziej umieszczają na szyldach nazwy rodzime. 


\section{Bibliografia}

BralCZYK J., 2000, Język na sprzedaż, Warszawa.

BrzózKa P., 2012, HP wprowadza się do Łodzi, [online] „Dziennik Łódzki” [dostęp 22.09.2012], http://www.dzienniklodzki.pl/artykul/606319,hp-wprowadza-siedo-lodzi,id,t.html.

Cieślikowa A., 2008, Mały słownik odmiany nazw własnych, Kraków.

GaŁKowski A., 2012, Chrematonimy w funkcji kulturowo-użytkowej. Onomastyczne studium porównawcze na materiale polskim, włoskim, francuskim, Łódź.

JARos V., 2008, Nazwy własne na sprzedaż, czyli funkcje nazw firm handlowych $i$ ustugowych $w$ marketingu [w:] Język marketingu, Michalewski K. (red.), Łódź, s. 357-365.

MATUSiaK I., 2010, Element wartościujacy w określeniach identyfikujących firmy [w:] Nazwy wtasne a społeczeństwo, Łobodzińska R. (red.), Łask, s. 295-304.

MaŃCZAK-Wohlfeld E., 2006, Angielsko-polskie kontakty językowe, Kraków.

Rzetelska-Feleszko E., 2006, $W$ świecie nazw własnych, Warszawa.

SIwIEC A., 2003, Nazwy handlowe i ich uwarunkowania społeczno-komunikacyjne (od kultury zideologizowanej do kultury skomercjalizowanej i reklamy) [w:] Metodologia badań onomastycznych, Bolik M. (red.), Olsztyn, s. 543-555.

—, 2003, Nazwy sklepów i firm handlowych jako przedmiot badań onomastycznych [w:] Przeszłość, teraźniejszość i przyszłość polskiej onomastyki, Łobodzińska R. (red.), Wrocław, s. 261-270.

Waszakowa K., 2005, Przejawy internacjonalizacji w słowotwórstwie współczesnej polszczyzny, Warszawa. 